\title{
Scope and management of Patient Registries for orphan rare disease (ORD) meeting the demands of all involved stakeholders
}

\author{
Elizabeth Hernberg-Ståhl \\ From 5th European Conference on Rare Diseases (ECRD 2010) \\ Krakow, Poland. 13-15 May 2010
}

Once a product for an ORD is approved; conditional or non conditional, there are still unanswered questions on long-term safety and effectiveness. And there is often limited knowledge on natural progression of the disease and optimal disease management. These questions could be answered by prospectively collecting real world data into patient registries.

The scope of the registry should be in line with demands from registry stakeholders such as regulatory agencies, payers, patients, treating physicians and the pharmaceutical industry.

Fabry and Hunter Outcome Surveys (FOS and HOS) supported by Shire Human Genetic Therapies have been designed and managed for almost 10 years in close collaboration with stakeholders.

Patient registries do meet challenges related to data completeness and quality. Treating physicians are not mandated to provide real world data to patient registries.

Over the years, global guidance on good practices for design, conduct, analysis and reporting of patient registry data have been developed to increase the quality and facilitate the usage of patient registry data. In addition, specific initiatives from FOS and HOS Governance bodies have been undertaken to increase the robustness of the collected data.

FOS and HOS have contributed to increased disease knowledge and improved disease management. Examples on findings are increased knowledge of the natural progression of the diseases, disease involvement in patient populations not eligible for inclusion into the

Correspondence: e.hernberg-stahl@latephasesolutions.com

Senior consultant, Late Phase Solutions Europe, Sommarvägen 6, 18360 Täby, Sweden initial clinical trials as well as long term clinical benefit of treatment.

However there are still questions to be addressed and answered especially to support pricing and reimbursement decisions in some European countries. This is to insure patients gets access to equal treatment on approved treatment independent of where they live in Europe.

Questions that need to be more closely addressed and evaluated are beyond clinical effectiveness and related to patients capacity to work and implications on public spending for these ORD.

Published: 19 October 2010

doi:10.1186/1750-1172-5-S1-O22

Cite this article as: Hernberg-Stăhl: Scope and management of Patient Registries for orphan rare disease (ORD) meeting the demands of all involved stakeholders. Orphanet Journal of Rare Diseases 2010 5(Suppl 1): $\mathrm{O} 22$.
Submit your next manuscript to BioMed Central and take full advantage of:

- Convenient online submission

- Thorough peer review

- No space constraints or color figure charges

- Immediate publication on acceptance

- Inclusion in PubMed, CAS, Scopus and Google Scholar

- Research which is freely available for redistribution

Submit your manuscript at www.biomedcentral.com/submit
Biomed Central 